\title{
POLITICIZATION OF RELIGION: RELIGION IN POLITICAL DISCOURSE
}

\author{
FAJAR SYARIF ${ }^{1}$ \\ Universitas Pamulang
}

\begin{abstract}
This article discusses the position of religion in politic that has relation to leadership. The main argumentation of this research is religion will constantly become a political power and social movement. In one side the research has different opinion from the integration politic paradigm and secular that proposed by Hasan al-Bannā and 'Al̄̄ Abd. al-Rāziq, but in another side, it has reinforced the two paradigms. By using literature study and descriptive method and philosophical historical approach, it indicates Islam will constantly exist and has influence in the political process. Although Islam is not depending on politic and on the contrary. Islam and politic are both integrated dimension of life, so both are not able to be separated from social politic dynamics.

Artikel ini membahas kedudukan agama dalam politik yang berkaitan dengan kepemimpinan. Argumentasi utama penelitian ini adalah bahwa agama tetap akan menjadi kekuatan politik dan gerakan sosial. Di satu sisi penelitian ini berbeda pendapat dengan paradigma politik integrasi dan sekuler yang dikemukakan oleh Hasan al-Bannā dan 'Al̄̄ Abd. al-Rāziq, namun di sisi lain memperkuat kedua paradigma tersebut. Dengan menempuh studi kepustakaan dan menggunakan metode deskriptif serta pendekatan filosofis dan historis, penelitian ini menunjukkan bahwa Islam akan tetap eksis dan berpengaruh dalam proses politik. Hakikat Islam meskipun tidak bergantung pada politik dan begitu pula
\end{abstract}

Corresponding author; email: ${ }^{1}$ fajarsyarif@gmail.com

ISSN 0852-7172 (p) 2461-064X (e)

(C) 2017 Walisongo: Jurnal Penelitian Sosial Keagamaan

http://journal.walisongo.ac.id/index.php/walisongo 
politik tidak bergantung pada Islam. Islam dan politik merupakan dua dimensi yang integral dalam kehidupan, maka keduanya tidak dapat dipisabkan dari dinamika sosial politik.

Keywords: Islam; politic; religion; state.

\section{Introduction}

Politicization of religion is a term developed as the effect of religion, dealing with mixing materials in Quran, Hadith, fatwa al-'ulamā' (agreement of Muslim Intellectuals), with political matters (Effendy 2005). Related to this idea, Jürgen Habermas states that religion takes a more role in politics. In fact, religion issues lead people in deciding their political action in presidential election and regional selection, law legalization and local regulation, even in state constitution (Habermas 2011). In addition, Michaella L. Browers declares that based on law and theology there is no dichotomy between religion and politics (Browers 2004). Meanwhile, Ziaul-Haq points out that Islam is open to religion pluralism (Ziaul-Haq 2010). Ayla Gol also reveals that debates between Muslim and Secular are not really the main problem, the main one is to build a connection between religion and politics as found in Turkey (Gol 2009).

Bassam Tibi defines politicization of religion as an effort to manipulate an understanding toward religion through propaganda, indoctrination, and campaign which are socialized to public (Tibi 1998; Tibi 2011). In another side, Muhammad Sa'̄̄d al-Ashmāwī explains politicization of religion as a concept which Allah creates Islam as a religion whereas people constructs it as political power (Al-Ashmāwī 1987). The two concepts disclosed by al-Ashmāwī and Bassam Tibi contrast each other. Bassam Tibi placed the politicization of religion in a negative side whereas alAshmāwī regards it as a moral control in running politics. 
Actually, the connection between religion and politics occur for historical aspect. When Prophet Muhammad saw. was still alive, he controlled both religion and state (politics) at the same time (Esposito 1998). When he died, a conflict occurred. His closed companions debated about who deserved to replace his position. Shī'ah surely thought that Prophet Muhammad saw. had prepared it well. It was based on hadith yaum al-indhār, hadìth manzīlah and hadīth al-ghadīr. Hadīth yaum al-indhār relates to words of Allah to remind Prophet Muhammad saw. reminded his relatives. Then, he invited Bani Hashim in a gathering to announce that whoever helped him in da'wah (delivering words of Allah), he would be his brother and khalifah (caliph). Ali Bin Abi Thalib was the only one who volunteered. This incident occurred around the tenth year before hijrah (Al-Tabar $\bar{\imath}$ 1939).

In hadìth manzìlah, Prophet Muhammad saw. said that the position of Ali bin Ab̄̄ Tālib was just like Hārūn for Mūsā. As stated in al-Quran, Hārūn is wāsi (a successor of Isa) when revelation is later given to him in Tursina hill. This hadith was popularized in Tabuk war (9 H) (Al-Hajjāj 2006).

Meanwhile, hadīth al-ghadì tells about Prophet Muhammad's words, witnessed by all Muslims in Ghadir Khum after their return of Wadā Hajj' (10 H), that declared Ali as his successor. This hadith is numerously mentioned as the most mutawātr one because it was narrated by 110 closed men of Prophet Muhammad. One of Sunni religious men, al-Hāfidh al-Dhahābiy strengthened this idea. Moreover, Ibn Jarīr al-Tabarī has collected hadith of Ghadir Khum in four volumes. I was amazed at having a chance to directly see half of these books and to feel their deep words so that I do believe in the stories told in them (Al-Husain 1967; Dhahābiy 1996). 
After Prophet Muhammad saw. died, half of the Muslims suddenly gathered in Saqîfah Banī Sa'īdah to decide the successor due to the prophet's death. Prophet Muhammad's closed relatives could not take a part in that gathering for taking care of the prophet's corpse. After a great debate between Anshar and Muhajirin, Abu Bakar was chosen as the next successor even though some of Anshar, such as Sa'ad bin 'Ubādah opposed the idea (Al-Tabari 1939). However, this system was not run in deciding the next successor. Abu Bakar directly chose 'Umar bin Khațtāb to replace him.

Umar bin Khattāb also applied and reinforced this system by forming ahl al-'aqd wa al-häl for choosing the next successor, Uthmān bin 'Affān. However, there was a little bit different in the systems done by Abu Bakar and Umar bin Khattāb'. In Abu Bakar's, the chosen successor should be from spontaneously ahl al-'aqd wa al-hāl formed. Another system occurred in choosing 'Alī bin Abī Tālib. He was chosen through Muslim acclamation at that time. Hence, there were various systems in choosing each successor (Al-Māwardī 1989; Sjadzali 1993).

Therefore, Muslim was split into two: Saqiffah who supported Abū Bakar and those who supported Alī bin Abī Tâalib through Ghadir Khum's deal. Some who supported Alī bin Abī Tāalib were 'Ammār bin Yāsir, Miqdād bin al-Aswad, Abū Dhār al-Ghifāriy, Salmān al-Fārisiy, Ibn Tayyihān, Jābir bin 'Abdullāh al-Ansāriy, Abū A'īd al-Khudriy, Khuzaimah Dhū al-Shahadatain, 'Abdullāh bin 'Abbās, etc (Ghitāa 1994; Muhammad 1963; Dāwud 1994). The split after the death of Prophet Muhammad saw. was the first rise of religion in public sphere.

Generally, the rise of religion in public sphere can be seen as the beginning of expanding values, principles, and symbols of Islam to society by utilizing public sphere for community. This sphere is used to communicate and negotiate numerous ideas 
and concerns, including religion matters. The exposure and discourse of Islam in the public sphere, however, contains the political dimension of various social forces that seek to publicly articulate the interests of the state (Kamil, Hasan, and Abubakar 2011). In a more general perspective, it can be stated that politicization of religion takes a part in constructing countries that have a religion-based constitution. Some of them are Iraq, Palestine, Iran, Pakistan, India, etc. This politicization of religion also comes to secular countries. As stated by Nawal El Saadawi, "There are no secular states. All states are religious". His statement is Saeedwi's sarcasm to question the consistency of secular countries (Al-Qurtubi 2009).

Thus, it can be revealed that religion takes a primordial role for a state. A lot of sociologists also thinks that this important role of religion in influencing political process in society. Peter Berger describes religion as strengths of world maintaining and world-shaking. For these strengths, religion is able to legitimize or to confront authority and privilege (Beger 2011; Effendy 2009). However, sociologist also agreed that the religion significance is decreased in public life due to secularization and privatization. The secularization leads to demonopolization of religious traditions and it increases chances for an amateur to take a part in. Since a lot of principals in religion go together and compete with non-religion principals, an understanding of religion should be rationalized and bureaucratized (Kunin 2005; Woodhead 2001).

My research related to religion and politics is quite rich research, among others, is Wasisto's research which reveals that religion can both influence and be influenced by politics. The implication is the emergence of political interpretation of religious texts which ultimately creates both sacralization and cult. Theology which formerly functioned diametrically between God and 
human beings as well as inter-human relationships now leads to the hierarchical process of God to human beings through the ulama and the state (Jati 2014). This is studied more deeply by Zuraini in his research that Islam is not merely a religion containing a set of ritual doctrines, but it also has a holistic, universal, and systematic worldview (Zuhraini 2014).

The close relationship between religion and politics has also been expressed by La Ode Machdani Afala, Muh. Tamar and Andi Murfi in their research that politics is a continuation of the prophetic mission in order to preserve religion and religion is the one controlling political affairs (La Ode, Tamar, and Murfi 2009). It is that way because Islam cannot be separated from politics even though Islam is not a political religion. The impact on Islamic and political affiliations are flexible, romantic, inclusive, and willing to compromise with power 'state' (Amirullah 2015).

Anang in his research states that the struggle about the relationship between religion and state raises three streams. First, it stands that Islam is a perfect religion, regulating all aspects of life including political or state affairs. Second, it argues that religion has nothing to do with the state, the affairs of religion and the state must be clearly separated. Third, there is an argument that there is no constitutional system in Islam but in it, there is a set of ethical values for the life of the state (Firdaus 2013).

Kamsi in his research reveals the relationship between religion and state also raises three paradigms, those are integralism, secularism, and substantivism. In Indonesia, the relationship between religion and the state is experiencing various scrimmage, starting from the confro ntational, reciprocally critical scrimmage to the accommodative one. However, in the current era of reform, the state has accommodated many Muslims' desires (religion) so that the relationship between religion and state is mutually symbiotic (Kamsi 2012). 
Based on the matter, this study reviews the relationship between religion and politics as an enrichment in Islamic studies to be applied in terms of leadership, so it can be seen how Islam talks about the problems of public life and the state.

This research is a kind of qualitative research, which includes the scope of library research, and prioritizes data from books, journals, documents and various literature related to the object of research (Zed 2008). The method used in this study is a descriptive method, which describes the content and descriptively analyzes texts (Sugiyono 2011). Descriptive research methods are not only limited to collecting data but also including analysis and interpretation of data, as well as comparing similarities and differences in phenomena found (Moleong 2002).

To ease the analysis process, a philosophical approach (Connolly 1999) is used as the main approach. According to Amin Abdullah, a philosophy used as a scientific approach has three traits. First, philosoph ical research is always directed to the search or formulation of ideas or ideas that are basically fundamental to the issues studied. Second, the introduction and the deepening of matters and fundamental issues can shape critical thinking. Third, the philosophical studies and approaches can shape the mentality, the way of thinking and personality that prioritize intellectual freedom, tolerance to any different views and beliefs, and is free of dogmatic and fanaticism (Abdullah 2000). In addition to the philosophical approach, this study also uses a historical approach because it is assumed that all events can be traced by looking into the past when the event occurred, where it happened, why it occurred, and who was involved in the event (Prayogo 2003).

\section{Discourses of Islam and State}

There are numerous concepts in defining a state spoken out by political experts, though the concepts have the same points. 
Roger H. Soltau, for instance, describes the state as an agency and authority that arranges and controls numerous problems in the name of society (Soltau 1961). The same understanding was also made by Miriam Budiarjo. He also termed the state as an agency (tool). That is the agency of the community that has the power to regulate human relationships in society (Budiarjo 2001). Similar to Soltau, Kamaruzzaman states that state is an agency of a powerful people who have control to rule society. It means that state is an area where people are controlled to pursue a kind of prosperity (Kamaruzzaman 2001). In other words, a portrays a state as an organization in certain area. Legally, that organization has power to force each person to follow regulation set in order to gain prosperity for them (Adnan 2007).

Basically, there are three main characters of a state: forcing, monopolizing and all-en compassing, all-embracing. The first characteristic is to force. In this case, government is required to force citizen in obeying all regulations to prevent vandalism. For this reason, a state needs to be legally legal taking physical actions. This right is usually given to police and army. The second characteristic is to monopolize. A state needs to have monopoly society in order take care for stability. It means that government has a right to ban certain religion and political parties if it is regarded as a disturbance for society. The third one is all-encompassing, all-embracing. In this point, it should be clearly stated that all regulations must be followed by all people, for example, there is no exception for people in paying tax (Sartono and Ahmad 2009). Besides, law domination must not occur in a state.

Furthermore, Miriam Budi arjo assumes that a state also needs to have other elements. The first one is religion. Each state must have its own region. It includes land, sea, and space. The second is a citizen. Each state must have citizen controlled by the government. The third is the government. Each state must have a 
formal institution to regulate its citizen. The fourth is sovereignty. It is the highest authority to arrange and to run constitution (Budiarjo 2001).

In Islam, it was noted that the connection between religion and state began at the end of $19^{\text {th }}$ century. Previously, this issue was not often debated as stated by Sukron Kamil, the connection between religion and state in classical thinking tradition completed each other. It is because Islam showed that political leadership was established to continue Prophet Muhammad lesson in maintaining religious and world issues (Kamil 2013).

In a perspective of old and medieval Islam, the connection between religion and state was based on social relationship assumption. It is because human beings naturally cannot fulfill their needs without any help from others. Humans are created to depend, to commune and to interact each other and these lead them to be a part of community (Sukardi 2009). Therefore, human beings do not only need each other but also individually and communally compete to gain prosperity. As confirmed by Sukron Kamil, the state is a kind of social cooperation and revelation has a role to guide into prosperity (Kamil 2013).

Apart from old and medieval classic concepts explained above, contemporary and modern Islamic thinkers propose three paradigms: integral, secular, and symbiotic. Further information about these three paradigms is as follows:

\section{Integral Paradigm}

Integral paradigm deals with an idea of integral connection between religion and state, both are like two sides of a coin that cannot be separated. Both are complementary parts of one another (Supriyadi 2014), even in a more general political meaning. This concept is created because Islam is a complete religion $(s h \bar{a} m i l))$ discussing all aspects of life, including poli- 
tics and economics. This concept is also known as "al-Islam dìn wa daulah (Islam is both religion and state)" (Yūsuf 1963; Jaib 1985). Islam is charity and ritual, state and nation (Black 2011). Islam is complete and touchable in all aspects of life. It is state and motherland, government and citizen, nobility and strength, love and justice, civilization and constitution, material and natural resources, income and wealth, struggle and lesson, force and thought, as well as a noble 'aqidah (behavior) and a right 'ibādah (worship) in a well-proportion (Al-Bannā 1990).

The explanation above reveals that Islam does not only give a lesson about human beings and God relationship but also a connection between human beings and political matters, even between human beings and natural resources (animal and plants). Sukron Kamil calls it organic typology. Islam and state connection is regarded as an organic one since it is an Islamic-based state and Islamic practitioners have a role in the executive state department. Kamil also explains that in organic typology, Islam is a complete lifestyle, not like generally accused by Westerners (Kamil 2013). This idea leads Bambang Pranowo to state that this paradigm obligate people to establish Islamic countries (Pranowo 2011).

Muhammad Rashīd Rịa, Sayyid Quțb, Hasan al-Bannā, dan Abū al-A'lā al-Maudūdiy are some of Islamic thinkers who are aware of Islam and state inseparability. In this case, khilafah is a supranational politic constitution after Prophet Muhammad saw. and the decade of 'Abbāsiyah. It has a responsibility to unite all Muslims. Also, to handle religion and world. An Indian thinker, al-Maudūdi also agrees that Islamic-based state is needed for words in al-Quran asks Muslims to obey Allah and His Prophets, and chosen leaders among them (Al-Maudūdiy 1967; I. Ahmad 2009).

Rosyada calls this paradigm as theocracy, which depicts religion and state as inseparability. It is because the government 
should be run based on words of Allah as well as regulations for human beings, nation and state (Rosyada 2003). Thus, it can be understood that matters of state and politics according to theocracy sect is a manifestation of God. This theocracy concept is also run by western countries, such as Netherlands. According to history, Netherland's King is known as a carrier of sacred duties, thus his authority is a holy mandate from God to proper his people (Suminto 1985).

However, this integral paradigm is criticized by al-Ashmāwī. He believes that traditionalist perspective reduces universality of Islam just for authority and money (Al-Ashmāwi 1987). According to him, this concept gives an understanding that Islamic state is a core point in learning Islam; politic is a main part of politic so that political practices are regarded as Islamic practices. Moreover, this integral paradigm brings an idea that establishing Islamic countries is a kind of obligation (Al-Ashmāwi 1987).

Similar ideas also delivered by Abdullāh al-Na'īm. He is an expert from Sudan who thinks that an idea of Islamic concept is an illusion and a kind of dangerous political concept. It is because state has a right to force people into accepting principals of shar $\vec{\imath} a h$ (Islamic lesson) whereas shar $\vec{\imath} a h$ should be accepted with a sincerity. Indirectly, this coercion leads to secular as the effect of authoritarian political domination, not qualified Islamic authority (An-Na'īm 2008).

\section{Secular Paradigm}

Secular paradigm is known as another concept that connects Islam and state. According to this paradigm, the state is not allowed to interfere in public matters. This paradigm separates the sacred and the profane, the religion and the state (Effendy 2009). Abdul Rāziq states that there is no any instruction in al-Quran focusing on establishing a state for Muslims and on system of 
khilafah (Al-Rāziq 1925). The secularization paradigm is accounted for by Al-Rāziq in al-Islām wa Usūl al-Hukm was once banned by Egyptian Islamic society and reported to the court. It was judged by the political theory developed in Egypt and the absence of a political concept or state in Islam, although using the system of khilafah (Syamsuddin 2001). Basically, secularization has something to do with displacement of Constantine Emperor from Rome to Byzantium (known as Constantinople) in $324 \mathrm{AD}$ (Zakaria 2003; Fuad 2009). Some experts of this paradigm, Tāhā Husain and 'Alī Abd. al-Razāq, point out that Islam is pure religion, it has nothing to do with matters of State (Muthhar 2016).

According to secular paradigm, religion is differentiated and separated from state. In a secular country, there is no connection between religion and the state system. The state is regarded as a horizontal subject between human beings and this world whereas religion is assumed as a vertical subject between human beings and God. In secular countries, their citizen has a right to choose their own belief, there is no intervention from government. Some countries practicing this paradigm are United States of America, England, France, and Germany (Mukhlas 2007).

European countries actually have a lot of experiences on state-religion connection. Consequently, they tend to not offer any freedom to choose to their citizen, but do a kind of intervention. However, industrial revolution and modernization changed many things to be better, including in religion side. This opinion is often termed "was losing its impact on political, economic, and intellectual life throughout industrial world". The idea to separate religion and politics first occurred in North European countries. Then, United States of America became the first country that got this legality from its constitution in $18^{\text {th }}$ century. United States of America was established through a conservative 
standard adopted liberal constitution system, framed as a secular state. America is a clear example of a country that separate state and religion. There, religion is regarded as a private space and it is not allowed to interfere in political system. Otherwise, politics cannot intervene religion matters. The secular ideas in United States of America are written in constitutional points. Thus, being secular is legal according to the state. This secular act does not occur for political parties' importance (Anderson 2004).

The process of this dialectics positions fragile externalization, objectification, and internalization that can turn transcendental perspective about God. If there is no enlightenment about this, people are going to be fragmented and existed. These religious values take significant roles as an inner dynamic in transforming more ethic and humanist social-cultural building (Casanova 1994). Modern secularism has an idea that religion symbols should be deleted because it causes conflicts. France is an example of a country that declares as a secular country and it makes them to continuously try omitting these symbols to be presented in public area. Initially, secularization in western countries in medieval era was purposed to break away from religious ties (Esposito 1998).

Politics is a term used to regulate society, ran by government, purposed to gain a great state (Noer 1982). Meanwhile, Azyumardi Azra says Islam is secular resistant due to lack of separation between Islam and politics in recent condition of Muslim society (Azra 2000). Islamic is a spiritual commitment to established justice while the state is a physical instrument to support the spiritual. If a state tends to ignore justice, it is because the spiritual commitment does not exist in it. Thus, religion has functioned to place back the spiritual in it (Mas'udi 2000). 
Symbiotic Paradigm

This paradigm believes that there is mutualism connection between state and religion. It also called symbiotic. In this paradigm, it is pointed out that religion needs state as an area where its values to be delivered and state needs religion as ethical and moral guidance. Even though Islam does not show its direction in a certain politics, but there are moral and ethical values for society and state in Islam (Choirie 2009; Al-Māwardiy 1989) and also ethical and moral guidance for live together with nature in Islamic ecosophy (Rusmadi 2016).

According to this paradigm, Islam neither prepares a clear political system nor lets Muslim and state-run without any guidance. Furthermore, Islam gives basic values that can be developed with a perspective of Islam itself. In other words, it is not wrong to adopt western ideas if it does not against values in Islam. Some thinkers developed this concept is Muhammad Abduh, Muhammad Iqbal dan Ibnu Khaldun.

Muhammad Iqbal assumes that religion and state should not be apart. Religion has a role to unite aspects in states based on orders of God. Thus, a state should be able to catch these orders for equality, companionship, and freedom taught by God. Indirectly, the state is an effort to transform these principals to be more applicable (Iqbal 1981).

In social-religious side, religion has a role to improve understanding about life. It includes relationship among human beings and God (habl min Alläh), the spiritual relationship among human beings ( habl min al-nās); political, economic, and social-cultural. Thus, there will be a problem if religion is only defined as habl min Allāh. In similar, if religion is only regarded as guidance (hujjah) in running life in the world, various problems will arise. 
Therefore, the state is a fundamental institution because it rules both human beings and social relationship. The state is also functioned to maintain a strong shar $\vec{\imath}$ at. Thus, religion is the foundation to have a true happiness (Al-Farabi 1993). In order to gain this, state is needed. In other words, religion is foundation and state is cantilever. Both of them depend on each other (Ridwan 2005).

In this concept, the state is important since it relates to the way in arranging and running government (Lubis 1981). The state has a role as regulation of " $m \bar{a}$ la yatimm al-din illā bih". The state makes people running their life by depending and helping each other (Z. A. Ahmad 1975).

Those paradigm explained above basically strengthen the idea that Islam is dynamic. Islam may become a powerful ideology that strongly controls and dominates various perspectives of human beings. In a certain context, there will be no problem if Islam is apart with state, even in extreme secular space. It is because the basic value in Islam is placed for each individual with condition he faced. If a state intervenes their society not to express their religion in public area, Islam does understand this reality for their wrong idea in destructing human rights and religion values. Meanwhile, symbiosis paradigm proposes an idea that Islam is an individual belief but it needs state in contexts of social and political. State also takes advantageous from religion, that is, to educate moral of officials, citizen, and politicians.

\section{The Role of Islam in Politics}

Despite the debate of political thought that has been alluded to earlier, Islam both theoretically and practically has a real role in human life, especially Muslims. In general, it can be said that Islam has transformed the immoral world in the field of politics, instead, has created the social-political life order to a 
higher civilization. Achmad Mubarak expressed that Islam since its presence is always in touch with political and state affairs. In fact, Islam is spread to the world not only through missionary but also through physical warfare and military expansion in the face of various powers. The fact is only a proof of the history of the existence of any Islamic state system, nonetheless the basis of the argument that Islam is a religion that is closely related to political issues (Mubarak 2011). Muhammad Natsir says that Islam is not just a religious system but a complete culture (Effendy 1996).

Not only Islam, religion as widely demonstrated by Smith, still has a role in politics in Europe. The role of religion in political development in Europe is very important. Religion has contributed to the limitation of governmental power and individual freedom, it is directly involved in the whole process of modernization through internal upheavals, interacting with the great ideologies of the present, encouraging the emergence of important political parties and also being one of the influential factors in the formation of political culture. Christian Democratic political parties have played a prominent role in the political arena in Western Europe, especially since the end of World War II. Meanwhile, Catholic political parties had taken control of the governments of Italy and West Germany. Although the church informally gave support to the parties, there was no formal relationship between the church and the party revealed by Smith (Smith 2009).

In the history of Islam, the concept of state formulated by ulama, at least contained two purposes, as proposed by M. Din Syamsuddin. First, to find the Islamic ideal of the state, both theoretically and formally. Meaning to say, it is an attempt to answer how the state forms in Islam. Secondly, to seek the idealization of Islam about the procedure of state administration, 
both the substantial search of state and the practical aspect of the state. This organizing procedure seeks to explain how the content of the country according to Islam (Syamsuddin 1993).

The reality of Islamic history also shows that the country is needed in the context of religious development ( $\left.d a^{\prime} w a\right)$. For example, when the Prophet Muhammad was still in Mecca (611$622 \mathrm{AD}$ ) and was not free to carry out his da'wah because the political power was dominated by the Quraysh who were hostile to the Prophet, but after the migration to Medina, the Prophet had had his own community who pledged faithful to live together with an agreement Mutually agreed upon, namely the Medina Charter. The life of the Prophet along with his people in this Medina period (622-632 AD) is considered a state life (Effendy 2005; Nasution 1986).

The history of Islam as it is briefly described above is evidence that Islam practically plays a role in the socio-political process. However, the problem is what and where the role of Islamic teachings in the socio-political process (Hikam 2000). The concept of Islamic politics is different based on the background and approach used (Al-Raīs 1960). The role of Islam is clearly visible from the emergence of Muslim scholars and intellectuals who respond to the concept of power sharing, such as Abdul Hamīd Mutawalli, who rejects the principle of popular sovereignty, because this does not guarantee the realization of freedom and the avoidance of authoritarianism of the ruler which can guarantee precisely the principle of power-sharing, the independence of the judiciary and the enforcement of the constitution (Mutawalli 1970). Mutawalli judged positively to the imitations of the principle of separation of powers that Montesquieu introduced, namely legislative (tashrī'iyyah), executive (tanfïdhiyah) and judiciary (qāuìyah). Indeed these three powers in the history of Islamic Caliphate held by a khalifah. However, 
the power of the caliph is not absolute, because he is limited by al-Quran and al-Sunnah (Mutawalli 1970). It is also later used as a basis for other Muslims, in giving the role of Islam to the state, such as Ayatollah Khomeini, Sayyid Qutub, Hasan al-Bannā, and Abū al-A'lā al-Maudūdi in terms of religion and state.

Medieval Muslim thinkers, such as Abū al-Asanasan 'Alī alMāwardi or Ibn Khaldūn also provide theories in the context of the Caliphate. Al-Māwardi, for example, who emphasizes his theory on the importance of the leadership of the ummah (imāmah), the position of the caliph as priest, and the duties and functions of the priest. The centrality of priests in government is of primary concern, not on the part of the process of forming the state. In other words, in terms of the role of Islam on the state, the approach used by al-Māwardi is more normative and doctrinaire, too focused on the personality of the leader, and does not pay attention to the sociological approach (Khan 2000).

Al-Māwardi formulated his thoughts by referring to the state practice of al-Khulafā al-Rāshidūn with the Umayyad and Abbasid dynasties, the theory of the appointment of head of state through du event, namely; (a) the election of the head of state by abl al-häl wa al-'aqd and (b) the appointment by the previous head of state (Al-Māwardi 1989). The first way is inspired by the state practice that exists in the period of al-Khulafā al-Rāshidūn and is often identified with the theory of social contract. This is because there is an agreement or agreement of imam and ablalhäl wa al-'aqd to exercise their rights and obligations respectively. This agreement is then continued with the bai'at of the people to the chosen imàm (Al-Rais 1960).

In practice, however, al-Māwardi still supports the second way, which means to justify the existing monarchy of power, a matter which was actually a general tendency at the time because of the generally authoritarian caliphate. Thus, the function 
of ahl al-hāl wa al-'aqd chose the head of state did not occur in Islamic history after the period of al-khulafā al-rāshidūn (AlMāwardi 1989).

Thought of al-Māwardi is not much different, even one stream with Ayatollah Khomeini who initiated the concept of wilayah al-faqìh. The concept is basically a continuation of the concept of Imāmah Shī'ah. In addition, this concept is identical to Khomeini's thought. Thus, to recognize this concept, we must examine his political thinking, which can be said to be the result of fusion of political theology, political philosophy, and political fiqh. From the very beginning, Khomeini always stressed that religion is not separate from politics with all its dimensions (Khomeini 2003; Eickelman 1998). According to him, the separation of religion and politics and the demand that the ulama do not interfere in socio-political affairs is a slogan propagated by imperialists, by which they can dominate and plunder all the resources of society. He also added that all forms of worship practiced in Islam are always related to politics and the preparation of society (Khomeini 1996; Anis 2013).

According to Khomeini, "establishing a government and forming an Islamic state is a wäjib kifayah for the fair fuqaha. After all, it is impossible to solve hisbiyyah cases-such as maintaining the public order, defending Muslim territory, keeping young people from deviations, fighting against anti-Islam propaganda, etc.- - without the establishment of a just Islamic government, and all this can only be realized by a just fuqaha" (Lakzai 2010). In Ibn Taymiyya's view, the obligation to establish the state, not based on the ijmā' as the opinion of most Sunni thinkers. He further emphasized that the existence of a state is an effort to realize the welfare of mankind and implement Islamic sharia. According to Ibn Taimiyyah the welfare of mankind can not be realized perfectly except with the community. To manage 
it cannot help but need a leader (Taimiyah 1988). Thus, establishing the state is a religious duty and the people must obey it. If not, then the positive goals will not be achieved (Effendi 2011). Ibn Taimiyah states that the purpose of the state is to implement the sharia of Islam for the realization of the welfare of the people, the birth and the mind and the establishment of justice in society (Taimiyah 1988).

Ibn Taymiyyah in his book al-amr bi al-ma'rüf wa al-nabyu 'an al-munkar, requires that the people be patient with the head of the zālim state and not fight him while he still performs the prayers (Taimiyah 1984). This opinion cannot be separated from Ibn Taymiyyah's view of the position of head of state in Islam.

A different view is conveyed by Al-Ghazāli, which states that the obligation of the formation of a state/government is wājib shar'ī based on ijmā 'ummah with the category fard kifāyah. Ijma 'ummah is meant to maintain sharia and religious order. That cannot be realized unless there is a ruler who is obeyed (government) (Al-Ghazāli 1972). Al-Ghazāli states that the world and the security of the soul and the treasures are not accomplished except by the presence of the obedient rulers. Therefore, people say: "religion and ruler are two twin brothers"; hence also people say "religion is the joint, while the ruler is the guard". Something that no joint (foundation) will be destroyed and something with no bodyguard will be in vain" (Al-Ghazāli 1975).

Ibn Khaldūn, who is in al-Ghazāli's view on religious and state relations, says that man is a social creature (al-insān madaniyūn bi al-bab'i), that man needs to live in society. Man cannot live alone. He needs each other to meet the diverse needs of his life. These needs require the division of labor and the existence of various businesses. Without it, it is difficult to create prosperity (Ash-Shiddieqy 2002). However, when living together, it is not impossible that a common problem arises, leading to disagree- 
ment. Therefore it is necessary to have a leader who can provide protection and decision of each issue. Thus, for Ibn Khaldūn, the khila fah is a requirement of religious law and the Muslims are obliged to uphold and defend (Khaldūn, n.d.; Effendi 2011).

In this case, Ibn Khaldūn said: "Appointing the head of state is obligatory. It has been known that its obligation is based on shara' and $i j m \bar{a}$ ' friends and täbi'in remembering that the friends of the Messenger of Allah swept Abū Bakar after the Prophet died and handed the community affairs to him. Similarly, it runs in each period after that. Never have people left in a state of non-leadership. All of these are merely ijm $\bar{a}$ ' which refers to the obligatory state head (Ash-Shiddieqy 2002).

Based on the above explanation, it is clear how Islamic thinkers play a role in the state with religion. Also, it can be imagined what is desired by Islamic thinkers.

\section{Leader: Between Religion and Politics}

The leader is the ultimate person, the most creative and has the ultimate goal. All of those criteria are impossible if he does not have the theoretical sciences and the virtue of thinking as a philosopher has (Al-Farabi 1995). In this sense, Al-Farabi assumes that the leader is the true owner (righteous king), the legislator and the priest have one meaning or refer to the same meaning (Al-Farabi 1996; Al-Farabi 1993).

Every religion has its own rules about the criteria of selecting a leader. This because the capacity of a leader in one country or region can do a very significant influence in determining the welfare of the community. From the legal side, the leader can determine a policy and affect the rules within a country or region. The leader is considered to be the absolute supreme powerholder in both the legislative and the judicial spheres. In Islam, the leader is called khadim al-ummah. This is because Islam con- 
siders leadership as task or responsibility (taklīf) and amānah; so, someone who is given this responsibility must prioritize the service for people. Most of the human beings perceive the leadership as an honor (takrim). They identify the leadership with authority by which they use to exploit people (Khairudin 2005; Hatta 2001).

For this reason, most humans compete for leadership seats to seek their own personal or group's popularity and advantage, while Islam requires leaders to nurture leaders under it, organize the intra-Muslim life and between Muslims and other faithful to achieve common prosperity under the auspices of Allah swt. What happens today is the political elites continuously do the maneuver to protect their power. As a result, it is not surprising that most of the people do not trust them (Noor 2007).

The Quran is a holy book that became the basis for Muslims in their lives. In the Holy Quran, there are various paradigms needed in Islamic studies and discourses. This scripture encourages observation and research. Therefore, according to M. Quraish Shihab, all groups of Muslims, whatever the background, always refer to the paradigm of the Quran to obtain answers or reinforce his opinion (Shihab 2013) Then, the verses of the Quran related to politics that lead to the politicization of religion (interpretation) in order to answer the political guidance itself.

There are several verses of the Quran which are important discussions in the succession of leadership, in which the verses relied on the prohibition of choosing pagan leaders. The kafir term (kafara) is a word interpreted to vary according to the Prophet's period of preaching in Mecca (Waldman 1968). It is revealed by Toshihiko Izutsu that the term " $k \bar{a} f i r$ " has to be translated comprehensively cannot be interpreted separately, the easiest to understand it with its antithetical "imān" (Izutsu 1967). 
Makārim al-Shirāji groups al-Quran, Âli 'Imrān: 28, in the category of political verse. According to him, this form of prohibition on the verse means a warning that everyone is cautious in alliances with non-Muslims, be careful if they want to appoint them as "auliya". The word auliya is the plural form of al-wali that means nāshir (helper), it is also said that a person who is given the responsibility to take care of worldly affairs and creatures' problems. This word is related to the word "wilayah" that means "al-sulthān" namely power (Al-Shirāji 1998; Manzur 2008). Sayyid Qutub is very extreme in questioning religious identity, he forbids a non-Muslim to be elected as a representative or a leader and puts them in a strategic position in a power and state. Even prohibited allied with them in all fields of both social and political affairs, including establishing bilateral relations with them. Qutub, in this case, assumes a religion other than Islam as an identity of disbelief (Qutb 1995).

In al-Quran, al-Nisā: 144, Tabattabā'i commented that the ban on coalition (electing) the Jewish or Christian leader was in the context of alliance or moral alliance and compassion (Tabattabā’i 1991). Kamāl Faqīh Îmānī commented on this verse by saying that the faithful have no right to accept the leadership of the unbelievers because they have a close relationship with the hypocrites (Imāni 1998).

In al-Quran, al-Māidah: 51, Fakhr al-Dīn interprets this verse as a general form of prohibition against alliance with Jews and Christians, as well as the prohibition of choosing them as leaders because of the hypocrisy of themselves, in the sense of an alliance with the people Which has the character of hypocrisy that can lead to the harm of the Muslims (Fakhr al-Dīn 1981, 17-18). While on al-Quran, al-Taubah: 23, Ibn Kathīr argues that what is meant by the term "al-kuffār" here is "al-Musyrikun. The point is forbidden to choose those who is musyrik as 
a leader. The mushrik is a trait of Allah's sharia (Kathīr 1992). Ibn Kathīr interprets the al-Quran, al-Taubah: 23, that as God's command, it is not allowed to lift up a kafir leader even though they are close relatives. Why? Because after that, they will certainly oppose their God and the messengers.

The scholars of interpretation explain that the cause of the decline of al-Quran, al-Mumtahanah: 1, is about the story of Hātib ibn Abī Balta'ah, one of the companions of the Prophet who immigrated to Medina. When Fath Makkah, Hātib took the initiative of secretly communicating with the Quraysh, Hātib sent a letter to those who reported that the Muslims would attack the Qurarians in Makkah, on the grounds that he was sorry for the Quraysh hoping that they would accept Islam rather than perish. But the messenger who brought the letter was caught and reported to the Messenger of Allah swt. So this verse goes down as a rebuke to him (Kathīr 1992).

A leadership-related interpretation cannot be separated from political interests, so identity politics becomes an important part of the interpretation. When the interpretation of some of the above verses is discussed in a political context, it will be a legitimacy of some groups to paganize each other. Yet if it happens to followers of Islam, then it could also happen to other religions who most likely assume that outside of their religion is kafir (Vaezi 2004).

Religious politicization is used as a tool of "black campaign" which became one of the strategies in defeating political opponents, it is dangerous to the continuity of religion itself, especially Islam. Mark V. Höhne said that when political conflicts within an area increase at a certain level of violence, then political identity exacerbates divisions on a larger scale and becomes a real threat (Höhne 2006). How religion can seem to be the cause of division of the Ummah when the Quran highlights the diversity 
as a sunnatullāh (al-Quran, al-Māidah: 48; Hūd: 118; al-Nahl: 93; al-Shūrā: 8).

As the experience of elections to elections, the level of conflict intensity is relatively increased. This is because, in the momentum of the election, various interests meet each other and compete in a competition. Limited seats of power and booming power enthusiasts make the candidate leaders compete and try to win the competition. Not infrequently they use the ways out of the corridor of law, norms, and ethics. Marchiavelism style is often displayed. It contains very high conflict vulnerabilities, related to the outbreak of conflict (Harahap 2005).

Significantly, the politicization of religion will be interesting and influential in the election of voters. For most of the verses that have been presented this represents a verse about identity politics in accordance with what is pigmented against the Quran. The paradigm of the Quran means the perspective of the Quran or the thorough sketches of the Quran regarding the politics of identity caused by the bias of the interpretation of the verses of the criteria of choosing the leader (Samuel 1990; Mas'ud 2010). This proves that religion and politics play a mutually supportive role in life. The scholars often consider the concept of political values in the Quran in a flexible way (Gokkir 2007). This movement tends to be carried out by scholars who engage in practical politics through cultural, symbolic, or psychological formation in society (Berntein 2005).

Therefore, Ibn Taymiyyah, in providing the requirement for a leader not to provide requirements related to the tribe or class, does not also provide excessive requirements. Ibn Taymiyyah besides expounding hadiths on obedience to the leader, though not from the Quraysh tribe also exposes and recognizes the truth of hadiths about Quraish. Only, he did not comment on the hadiths. There are nine hadith quoted by Ibn Taymiyyah about the 
leadership of the Quraysh, except that the hadith texts do not expressly require that the leader should be of Quraish. For him, the main requirements for leaders are amānah (honesty) and $q u$ wwah (strength) (Shobahussurur 2008).

In Ibn Taymiyya's concept, power is a mandate that must be upheld. Then a leader of a country, or other leaders of lower rank, must be able to convey the amānah to its owner (al-Quran, al-Nisā: 58). The leader should be chosen an honest man, can carry the amānah. In a hadith mentioned "when the mandate has disappeared, then just wait for its destruction. When did the mandate disappear?. He replied: if a business is handed over to someone who is not an expert, then wait for its destruction" (AlBukhāri 1987). That is the leader of aminn (honest, who can hold amānah) that can uphold justice (Shobahussurur 2008).

Donald Eugene Smith reveals that political actors related to religion, such as religious leaders or religious functionaries have a great influence on the political atmosphere. Yet Islam is very influential on the formation of political culture proposed by Sidney Verba is a culture of a political society. Political culture in question consists of tools such as empirical belief systems, symbols, and values that determine the situation at the time of the political process (Smith 2009; Verba 1965)

\section{Conclusion}

Ending this study, based on facts and descriptions, it can be concluded that Islam does not only have a very important role in social and political life, but more than that Islam in its particular form will still exist as an ideology of political movement. The process of Islamic influence in politics is manifested in the context of social life of society, that religion and politics have a very close relationship. Religion is fundamental to society. Religion is always in the body of society. The power that exists within the 
religion defeats other forces. Therefore, religion is often brought by politics to legitimize politics so as to impress politicize religion especially in terms of leadership.

Religion in a society is one of many sources of attitudes and values in politics. The higher dogmatic religious system will strengthen the political tendency, and the lower dogmatic religion will debilitate the political tendency. In Islam, dogmatic is very strong. Islamic truth is believed to be absolute, universal and immutable. The Quran is believed to be azali. The dogmatic authority in Islam directs the political life of a society to an ideological orientation.

\section{Bibliography}

Abdullah, Muhammad Amin. 2000. "Rekonstruksi Metodologi Studi Agama Dalam Masyarakat Multikultural Dan Multirelijius.” In Antologi Studi Islam: Teori \& Metodologi, edited by Muhammad Amin Abdullah. Yogyakarta: Sunan Kalijaga Press.

Adnan. 2007. Ilmu Politik: Pengantar Pemikiran Politik Islam. Gorontalo: Sultan Amai Press.

Ahmad, Irfan. 2009. "Geneology of Islamic State: Reflection on Maududi's Political Thought and Islamism." Journal of Royal Anthropological Institute 15 (2): 145-62.

Ahmad, Zainal Abidin. 1975. Konsepsi Negara Bermoral Menurut Imam Al-Ghazali. Jakarta: Bulan Bintang.

Al-Ashmāwi, Muhahmmad Sa'id. 1987. Al-Islām Al-Siyāsi. Sina li al-Nashr: al-Tabah.

Al-Bannā, Hasan. 1990. Majmū'ah Rasāil. Iskandariyah: Dār alDa'wah.

Al-Bukhāri, Muhammad ibn Ismail Abu Abdillah al-Ja'fr. 1987. Al-Jāmi’ al-Sahīh al-Mukhtasar. Beirut: Dār Ibnu Katsir. 
Al-Farabi, Abū Nasr Muhammad ibn Tarkhan. 1993. Kitāb al-Siyāsah Al-Madaniyah. Beirut: Dār al-Mashriq.

- 1995. Tahsīl al-Sa’ādah. Beirut: Maktabah al-Hilāl.

_. 1996. Kitāb Āra’ Ahl al-Madīnah al-Fādilah. Beirut: Dār al-Mashri.

Al-Ghazāli, Abū Hāmid Muhammad. 1972. Al-Iqtisād fî alI’tiqād. Mesir: Maktabah al-Jund.

—. 1975. Ihyā 'Ulūm al-Dīn. Beirut: Dār al-Fikr.

Al-Hajjāj, Muslim Ibn. 2006. Sahīh Muslim. Riyād: Dār Tayyibah.

Al-Husain, Amīnī Abdul. 1967. Al-Ghadīr. Beirut: Dār al-Kitāb al-'Arabī.

Al-Maudūd̄̄, Abū al-A'lā. 1967. Nazariyyah al-Islām al-Siyāsiyah. Damascus: Dar al-Fikr.

Al-Māwardī, Abū al-Hasan 'Alī. 1989. Al-Ahkām al-Sultāniyah wa al-Wilāyah al-Dinniyah. Kuwait: Dār Ibn Qutaibah.

Al-Qurtubi, Sumanto. 2009. "Dari Sekularisasi Ke Politisasi Agama." The Wahid Institute, July.

Al-Raīs, Muhammad Diyā al-Dīn. 1960. Al-Nazariyāt al-Siyāsiyat al-Islāmiyat. Cairo: Anjlu al-Misriyat.

Al-Rāziq, Alī Abd. 1925. Al-Islām wa Usūl al-Hukm: Bahthun F̄̄ Al-Khilāfah Wa Hukūmah. Cairo: Matba'ah Misr.

Al-Shirājī, Makārim. 1998. Tafsīr Al-Amthāl. Qum: al-Matba'ah Amīr al-Mukminīn.

Al-Tabarī, Ibn Jarīr. 1939. Tārikh al-Umam wa al-Mulk. Cairo: al-Istiqlāl.

Amirullah. 2015. "Hubungan Islam Dan Politik Di Indonesia Serta Implikasinya Terhadap Pendidikan Islam.” Jurnal Ilmiah "Kreatif" 12 (1): 1-17. 
An-Na'īm, Abdullah Ahmed. 2008. Islam and The Secular State: Negotiating the Future of Sharia. London: Harvard University Press.

Anderson, Brian. 2004. "Secular Europe, Religious America." Journal of The Public Interest 4 (1): 143-56.

Anis, Muhammad. 2013. Islam Dan Demokrasi Perspektif Wilayah al-Faqih. Bandung: Mizan.

Ash-Shiddieqy, Hasbi. 2002. Islam Dan Politik Bernegara. Semarang: PT Pustaka Rizki Putra.

Azra, Azyumardi. 2000. "Islam Di Tengah Arus Transisi Menuju Demokrasi.” In Islam Di Tengah Arus Transisi, edited by Mun'im Abdul, 17. Jakarta: Kompas.

Beger, Peter L. 2011. The Sacred Canopy: Elements of Sociological Theory of Religion. New York: Open Road Integrated Media.

Berntein, Mary. 2005. "Identity Politics, Source: Annual Review of Sociology." Journal Islamic Studies 3 (2): 47-74.

Black, Antony. 2011. The History of Islamic Political Thought: From the Prophet to the Present. Edinburgh: Edinburgh University Press.

Browers, Michaelle L. 2004. "Shahrur's Reformation: Toward a Democratic, Pluralist and Islamic Public Sphere." Journal of Historical Reflection/Réflexions Historiques 30 (3): 445-67.

Budiarjo, Miriam. 2001. Dasar-Dasar Ilmu Politik. Jakarta: Gramedia Pustaka Utama.

Casanova, José. 1994. Public Religions in the Modern World. Chicago: University of Chicago Press.

Choirie, A Effendy. 2009. Islam-Nasionalisme UMNO-PKB: Studi Komparasi Dan Diplomasi. Jakarta: Pensil 324. 
Connolly, Peter. 1999. Approaches to the Study of Religion. London: Cassel.

Dāwud, Nabīlah 'Abd. al-Mun'im. 1994. Nash'atu Al-Shī'ah Al-Imāmiyah. Beirut: Dār al-Mu'arrikah al-'Arabī.

Dhahābī. 1996. Siyar al-A'lāmi al-Nubalā. Beirut: Muassasah alRisālah.

Effendi, Mukhlison. 2011. "Politik Kenegaraan Dalam Islam; Studi Komparasi Pemikiran Al-Ghazali, Ibnu Taimiyah Dan Ibnu Khaldun.” Dialogia Jurnal Studi Islam Dan Sosial 9 (2): 158-84.

Effendy, Bahtiar. 1996. "Islam Dan Demokrasi: Mencari Sebuah Sintesa Yang Memungkinkan.” In Agama Dan Dialog Peradaban, edited by M. Nasir Tamara and Elza Peldi Taher, 92-93. Jakarta: Paramadina.

- 2005. Jalan Tengah Politik Islam: Kaitan Islam, Demokrasi Dan Negara Yang Tidak Mudah. Jakarta: Ushul Press.

- 2009. Agama Publik Dan Privat: Pengalaman Islam Indonesia. Jakarta: PPIM UIN Jakarta and UI Press.

Eickelman, Dale. 1998. Ekspresi Politik Muslim. Bandung: Mizan.

Esposito, John L. 1998. Islam and Politic. New York: Syracuse University Press.

Firdaus, Muhammad Anang. 2013. "Relasi Agama Dan Negara: Telaah Historis Dan Perkembangannya." Jurnal Multikultural \& Multireligius 13 (3): 165-74.

Fuad, Ahmad Nur. 2009. "Sekularisasi Politik: Pengalaman Amerika Serikat Dan Dunia Islam.” Jurnal Universitas Muhammadiyah Malang (UMM) 12 (2): 78-104.

Ghitā, M. H. Kāshif. 1994. Aslu Shī’ah Wa Usūluhā. Qum: Mu'assasah al-Imām 'Alī. 


\section{POLITICIZATION OF RELIGION}

Gokkir, Neemettin. 2007. Political Language of Tafsir, Redefining of "Ummah", A Religio-Communal Concept of the Qur'an: Past and Present. Istanbul: Universitesi Ilahiyat.

Gol, Ayla. 2009. "The of Turkey: Muslim and Secular.” Journal of Third World Quarterly 30 (4): 795-810.

Habermas, Jürgen. 2011. Religion in the Public Sphere.” In The Power of Religion in the Public Sphere. Edited by Jonathan Mendieta, Eduardo and Van Antwerpen. Columbia: Columbia University Press.

Harahap, Abd. Asri. 2005. Manajemen Dan Resolusi Konflik Pemilukada. Jakarta: Cidesindo.

Hatta, Mohammad. 2001. Karya Lengkap Bung Hatta. Jakarta: LP3ES.

Hikam, Muhammad AS. 2000. Islam, Demokratisasi Dan Pemberdayaan Civil Society. Jakarta: Erlangga.

Höhne, Markus V. 2006. "Political Identity, Emerging State Structures and Conflict in Northern Somalia." Journal of Modern African Studies 44 (3): 397-414.

Îmān̄̄, Kamāl Faqīh. 1998. Nūr al-Qur'ān: An Enlightening Commentary Into The Ligh of The Holy Qur'àn. Iran: Imam Ali Public Library.

Iqbal, Muhammad. 1981. The Reconstruction of Religious Thought in Islam. New Delhi: Kitab Bhavan.

Izutsu, Toshihiko. 1967. "Ethico-Religious Concepts in the Qur'an." Journal of the Contemporary Religions in Japan 8 (2): 186-90.

Jaib, Sa'd Abū. 1985. Dirāsah fī Manhaj al-Islām Al-Siyāsī. Beirut: Mu'assasah al-Risālah.

Jati, Wasisto Raharjo. 2014. “Agama Dan Politik: Teologi Pembebasan Sebagai Arena Profetisasi Agama.” Walisongo: Jurnal Penelitian Sosial Keagamaan 22 (1): 133-56. 
Kamaruzzaman. 2001. Relasi Islam dan Negara. Magelang: Indonesia Tera.

Kamil, Sukron. 2013. Pemikiran Politik Islam Tematik; Agama dan Negara, Demokrasi, Civil Society, Syari'ah Dan HAM, Fundamentalisme Dan Antikorupsi. Jakarta: Kencana Prenada Media Group.

Kamil, Sukron, Noorhaidi Hasan, and Irfan Abubakar. 2011. Islam di Ruang Publik, Politik Identitas dan Masa Depan Demokrasi di Indonesia. Jakarta: Center for the Study of Religion and Culture (CSRC) UIN Syarif Hidayatullah Jakarta.

Kamsi. 2012. "Paradigma Politik Islam Tentang Relasi Agama Dan Negara." IN RIGHT Jurnal Agama Dan Hak Azazi Manusia 2 (1): 41-68.

Kathīr, Abū al-Fidā Ismā’̄il bin 'Umar ibn. 1992. Tafsìr al-Qur'ān al-'Azìm. Beirut: Dār al-Fikr.

Khairudin. 2005. Menuju Partai Advokasi. Yogyakarta: Tokoh Bangsa.

Khaldūn, Ibn. n.d. Muqaddimah. Beirut: Muwassasat al-Alamī li al-Matbuah.

Khan, Qamaruddin. 2000. Kekuasaan, Pengkhianatan Dan Otoritas Agama: Telaah Kritis Teori Al-Mawardi Tentang Negara. Yogyakarta: Tiara Wacana.

Khomeini, Ayatulah. 1996. Al-Hukümah Al-Islämiyah. Teheran: Muassasah Tanīm wa al-Nasr Turāth Imām Khomeini.

_. 2003. Tahrīr al-Wasillah. Qum: Muassasah al-Nasr al-Islāmi.

Kunin, Seth Daniel. 2005. Religion: The Modern Theories. Edinburgh: Edinburgh University Press.

Lakzai, Akbar Najaf. 2010. Dinamika Pemikiran Politik Imam Khomeini. Edited by Muchtar Luthfi. Jakarta: Sadr Press. 


\section{POLITICIZATION OF RELIGION}

Lubis, M. Solly. 1981. Ilmu Negara. Bandung: Alumni.

Manzur, Ibn. 2008. Lisān al-'Arab. Beirut: Dār al-Sadr.

Mas'ud, Abdurrachman. 2010. Paradigma Pendidikan Islam. Yogyakarta: Pustaka Pelajar.

Mas'udi, Masdar Farid. 2000. "Islam Dan Negara Kebangsaan.” In Islam Di Tengah Arus Transisi, edited by Abdul Mun'im, 44-50. Jakarta: Kompas Gramedia.

Moleong, Lexy J. 2002. Metode Penelitian Kualitatif. Bandung: Remaja Rosda Karya.

Mubarak, Achmad. 2011. "Daulah Islamiyah vs Daulatul Muslimin, Salah Paham Negara Islam.” In Chiefdom Madinah: Salah Paham Negara Islam, edited by Abdul Aziz. Jakarta: Pustaka Alvabet.

Muhammad, Abduh. 1963. Sharh Nahj Al-Balāghah. Beirut: Dār al-Ma'rifah.

Mukhlas, Sunaryo. 2007. "Islam Dalam Pergumulan Elit Politik Indonesia.” Khazanah Jurnal Ilmu Agama Islam 4 (12): 337-65.

Mutawalli, Abdul Hamīd. 1970. Amzah Al-Fikr Al-Siyāsī Al-Islām fi Asr al-Hadìth. Iskandariyat: al-Maktabah al-Misr al-Hadìth li al-Taba'ah wa al-Nashr.

Muthhar, Moh. Asy'ari. 2016. Masyarakat Dan Negara Menurut Al-Farabi: Relevansi Dengan Pemikiran Politik Modern. Jakarta: Fananie Center.

Nasution, Harun. 1986. Islam Ditinjau Dari Berbagai Aspeknya. Jakarta: UI-Press.

Noer, Deliar. 1982. Pemikiran Politik Di Negeri Barat. Jakarta: Rajawali Press.

Noor, Firman. 2007. "Kegagalan Partai Politik Menarik Simpati Rakyat." Jurnal Penelitian Politik 4 (1): 48-63. 
Ode, Machdani Afala La, Muh Tamar, and Andi Murfi. 2009. "Pengaruh Agama Dalam Sistem Pemerintahan Negara (Studi Kasus Sistem Pemerintahan Republik Islam Iran)." Government: Jurnal Ilmu Pemerintahan 2 (2): 145-54.

Pranowo, Bambang. 2011. “Konsep Negara Dalam Islam.” In Chiefdom Madinah: Salah Paham Negara Islam, edited by Abdul Aziz, vii. Jakarta: Pustaka Alvabet.

Prayogo, Imam and Tobroni. 2003. Penelitian Sosial Agama. Bandung: Remaja Rosda Karya.

Qutb, Sayyid. 1995. Tasìr F̄̄ Zilāl Al-Quran. Beirut: Dār alShurūq.

Ridwan, Mursyidi. 2005. "Konsep Politik Kenegaraan Dalam Islam.” Jurnal Justitia Islamica 2 (2): 78-102.

Rosyada, Dede. 2003. Pendidikan Kewargaan: Demokrasi, Hak Asasi Manusia, Dan Masyarakat Madani. Jakarta: ICCE UIN Syarif Hidayatullah.

Rusmadi. 2016. "Ecosophy Islam: Studi Tematis Kontekstual Nilai-Nilai Etika Lingkungan Dalam Islam.” Jurnal Smart 02 (02): 237-48.

Samuel, Thomas Khun. 1990. The Structured of Scientific Revolution. Chicago: Chicago University Press.

Sartono, Zain, and Ahmad. 2009. "Karakteristik Pemerintahan Islam." Koordinat Jurnal Komunikasi Antar Perguruan Tinggi Agama Islam Swasta 10 (1): 26-27.

Shihab, M. Quraish. 2013. Kaidah Tafsir. Tangerang: Lentera Hati.

Shobahussurur. 2008. "Proses Pemilihan Pemimpin Menurut Ibn Taimiyah.” Refleksi Jurnal Kajian Agama Dan Filsafat $10(2): 172$.

Sjadzali, Munawir. 1993. Islam Dan Tata Negara. Jakarta: UI Press. 


\section{POLITICIZATION OF RELIGION}

Smith, Donald Eugene. 2009. Religion and Political Development: An Analytic Study. Brown: University of Michiga.

Soltau, Roger F. 1961. An Introduction to Politics. London: Longmans.

Sugiyono. 2011. Metode Penelitian Kombinasi (Mixed Methods). Bandung: Alfabeta.

Sukardi, Imam. 2009. "Pemikiran Politik Al-Farabi." Jurnal Pemikiran Dan Peradaban Islam: Islamia 5 (2): 25-39.

Suminto, Aqib. 1985. Politik Islam Hindia Belanda. Jakarta: LP3ES.

Supriyadi, Muhammad. 2014. Demokrasi, Pemilu, Dan Isu SARA; Perspektif Rasional. Jakarta: Pensil 324.

Syamsuddin, M. Din. 1993. "Usaha Pencarian Konsep Negara Dalam Sejarah Pemikiran Politik Islam.” Jurnal Ulumul Quran 4 (2): 1-29.

- 2001. Islam Dan Politik: Era Orde Baru. Ciputat: Logos Wacana Ilmu.

Tabattabā'̄i, Muhammad Husain. 1991. Al-Mīzān fī Tafsìr al-Quran. Beirut: Mu'assasah li al-'Ālam li al-Mabū'ah.

Taimiyah, Ibn. 1984. Al-Amr bi al-Ma'rūf aa al-Nabyu 'an al-Munkar. Beirut: Dār al-Fikr.

- 1988. Al-Siyāsah Al-Shar'iyyah fī Islāh al-Rā'i aa alRā'iyah. Beirut: Dār al-Kutub al-Ilmiah.

Tibi, Bassam. 1998. The Challenge of Fundamentalism: Political Islam and the New World Disorder. London: University of California Press.

- 2011. "The Politicization of Islam and Islamism in the Context of Global Religious Fundamentalism." Journal of the Middle East and Africa 1 (1): 153-70.

Vaezi, Ahmad. 2004. Shia Political Thought. London: Islamic Centre of England. 
Verba, Sidney. 1965. Political Culture and Political Development. Princeton: Princeton University Press.

Waldman, Marlyn Robinson. 1968. "Development of the Concept of Kufr in the Qur'an." Journal of the American Oriental Society 88 (3): 442-55.

Woodhead, Linda. 2001. The Study of Religion. London: Routledge.

Yūsuf, Muhammad Mūsā. 1963. Nizām al-Hukm fī al-Islām. Cairo: Dār al-Kitāb.

Zakaria, Fareed. 2003. The Future of Freedom: Liberal Democracy at Home and A Broad. New York and London: W.W. Norton \& Company.

Zed, Mestika. 2008. Metode Penelitian Kepustakaan. Jakarta: Yayasan Obor Indonesia.

Ziaul-Haq, Muhammad. 2010. "Religious Diversity: An Islamic Perspective.” Journal of Islamic Studies 49 (4): 493-519.

Zuhraini. 2014. "Islam: Negara, Demokrasi, Hukum Dan Politik." Analisis: Jurnal Studi Keislaman 14 (1): 29-57. 